\title{
Chemical corrosion of concrete tank in sewage treatment plant as the cause of failure
}

\author{
Piotr Woyciechowski ${ }^{1, *}$, Grzegorz Adamczewski ${ }^{1}$, and Paweł Łukowski ${ }^{1}$ \\ ${ }^{1}$ Warsaw University of Technology, Faculty of Civil Engineering, Department of Building Materials \\ Engineering, 00-637 Warsaw, al. Armii Ludowej 16, Poland
}

\begin{abstract}
The organoleptic examination proves a significant degree of structural disintegration of concrete - some loosely embedded aggregate grains easily fall out when touched. The vertical range of the above changes includes a zone up to approx. $60 \mathrm{~cm}$ above the wastewater level, i.e. thea zone of fluctuations in the level of wastewater and a spray-gas zone. In the case of the tank $01 / 1$ this means the full usable height of the tank, which may mean in the longer term the propagation of damage to the lower surface of the roof.
\end{abstract}

\section{Introduction}

Reinforced concrete tanks in wastewater treatment plants are designed for a minimum service life of 50 years. The internal surface of such tanks is exposed to many aggressive factors, including those usually corresponding to exposure classes XA3 and XF2 [1]. Providing the required durability in these difficult conditions requires of an adequate choice of solutions in the field of construction, structural and surface protection at the stage of reservoir design as well as the execution diligence at the construction stage [2].

In the municipal sewage treatment plant, which is the subject of this paper, considerable concrete damages were found in the walls of some reinforced concrete tanks after three years of their use. On the internal surfaces of these reservoirs, after such a short period of use, large surface defects in reinforcement cover were detected and their depth was estimated to be $1-2 \mathrm{~cm}$ on the basis of a visual assessment.

The subject of this article is the identification of environmental and material causes of rapid degradation of concrete in pre-treatment tanks.

For the tanks, where numerous concrete damages were found, the following actions were carried out:

- general assessment of the technical condition of internal concrete surfaces of pretreatment tanks on the basis of the inspection,

- gathering of the information related to the structure on the basis on the archival technical documentation,

- analysis of the environmental factors affecting concrete in the structure, including laboratory tests of sewage samples collected at various stages of the technological

\footnotetext{
* Corresponding author: P.Woyciechowski@il.pw.edu.pl
} 
treatment process and laboratory tests of samples of the gas environment collected above the wastewater level.

- concrete tests, including:

- macroscopic surface evaluation,

- estimation of concrete composition,

- assessment of compressive strength based on core drilling,

- evaluation of the homogeneity of mechanical features on the basis of sclerometer tests,

- assessment of surface tensile strength,

- assessment of resistance to freezing and thawing,

- analysis of the causes of damages on the basis of the results of material tests and the results of the analysis of the environment.

For the purpose of comparison, selected diagnostic activities were carried out simultaneously in one of the tanks in which no signs of concrete destruction were found during the initial inspection.

\section{Technological and technical description of the treatment plant}

The treatment plant consists of three main objects (Figure 1), the first and second of which include pre-treatment devices (technical building - building 01 and grit chambers - building 02), and the third is a biological reactor (SBR) with accompanying facilities (building 03).

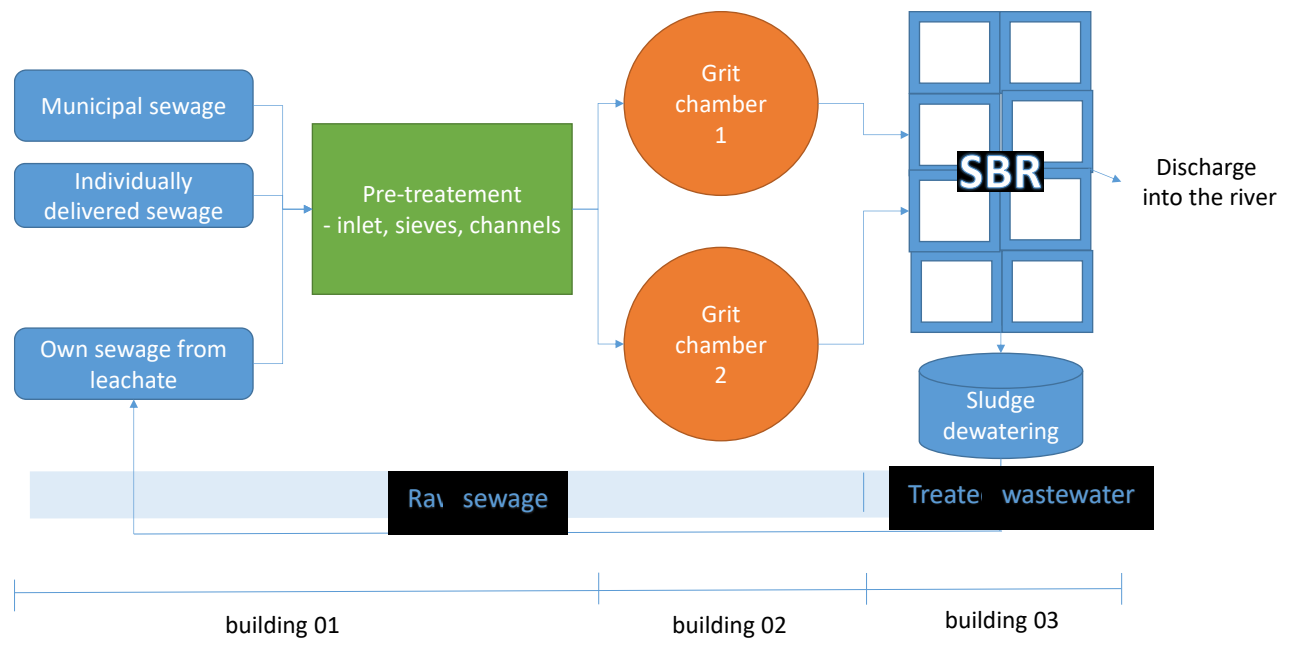

Fig. 1. Technological scheme of treatment process.

Raw sewage, which flows into the building 01, are subject to subsequent stages of mechanical cleaning in the building 02 . In th building 03 , pre-treated sewage is subject to a further treatment - biological process - with the use of the activated sludge. This means that the walls of the subsequent tanks in the technological line are in contact with the gradually changing environment. This influences the assessment of the environmental aggressiveness in subsequent tanks and may lead to the determination of different concrete exposure classes, presumably towards less aggressive environment at the final stage of the treatment [2].

The design of the reinforced concrete structure of the sewage treatment plant was made in accordance with PN-B-03264:2002 standard. In the building 01, which has a monolithic reinforced concrete structure, there are two rectangular tanks - the upper one 
(01/1 in Fig. 2) and the lower one (01/2 in Fig. 2). The depth of the upper reservoir, which has the character of flow channels, is $1.28 \mathrm{~m}$ with local dredging to $2.85 \mathrm{~m}$, and the depth of the lower reservoir $-3.30 \mathrm{~m}$.

In the building 02 there are two cylindrical tanks (02/1 and 02/2 in Fig. 2) with an inside diameter of $4 \mathrm{~m}$ and a total height of $6.62 \mathrm{~m}$. They are connected with a multi-chamber set of rectangular tanks (02/3 in Fig. 2) with heights from $2.62 \mathrm{~m}$ to $7.87 \mathrm{~m}$, ended with a pipe that leads the pre-treated wastewater to the building 03 .

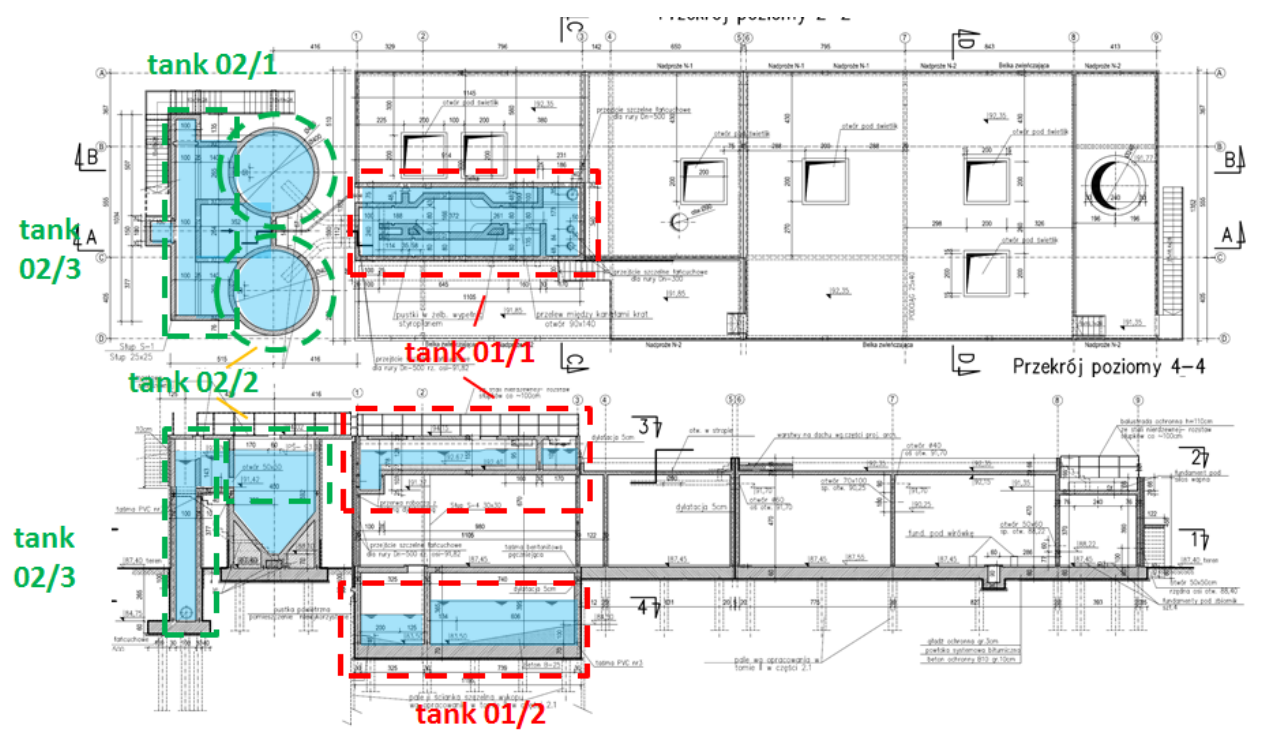

building 02

building 01

Fig. 2. Location of tanks in buildings 01 and 02 .

\section{Diagnostics of the tanks}

The symptoms of concrete degradation were found in the tanks located in the buildings 01 and 02 , therefore the diagnostic activities related to the structure were carried out in the full range in the selected places of these tanks. The samples were also taken for comparison in the tank 03, where no concrete destruction was found. The tests of the corrosive environment were performed on the samples of the sewage and air taken at various stages of the sewage treatment.

The initial visual inspection and initial review of the documentation made it possible to specify the following main research and analysis objectives (Figure 3):

- determination and documentation of the condition of the tank walls,

- determination of the causes of damages found,

- collecting of the data for the durability prognosis and for developing of a repair concept.

Structural concrete in the tanks in the buildings 01 and 02 was designed as a watertight concrete W8 of the compressive strength class C30/37 (B37), with cement CEM III/A 32.5 N-NA HSR LH. The use of AIIIN class reinforcing steel (grade RB500W) was assumed. A structural protection of the concrete and surface protection in the form of internal, chemical-resistant, two-layer, bitumen-epoxy insulation resistant to abrasion were predicted. 
The exposure classes for the concrete surfaces of all tanks were adopted as follows:

a) internal surfaces:

- the zone from the level of $0.5 \mathrm{~m}$ below the range of changes in the level of sewage to the crown of tanks - exposure class XA3, if the chloride ions concentration $\leq 500 \mathrm{mg} / \mathrm{l}$,

- the zone from the bottom to the level of $0.5 \mathrm{~m}$ below the range of changes in the level of sewage and the bottom of the tanks - exposure class XA1,

b) external surfaces:

- elements being in contact with the ground - exposure class XA1,

- external surfaces of the part above the ground - exposure class XF1.

The subject of the inspection were accessible internal surfaces of tank walls, having contact with the sewage and their vapours (Fig. 4).

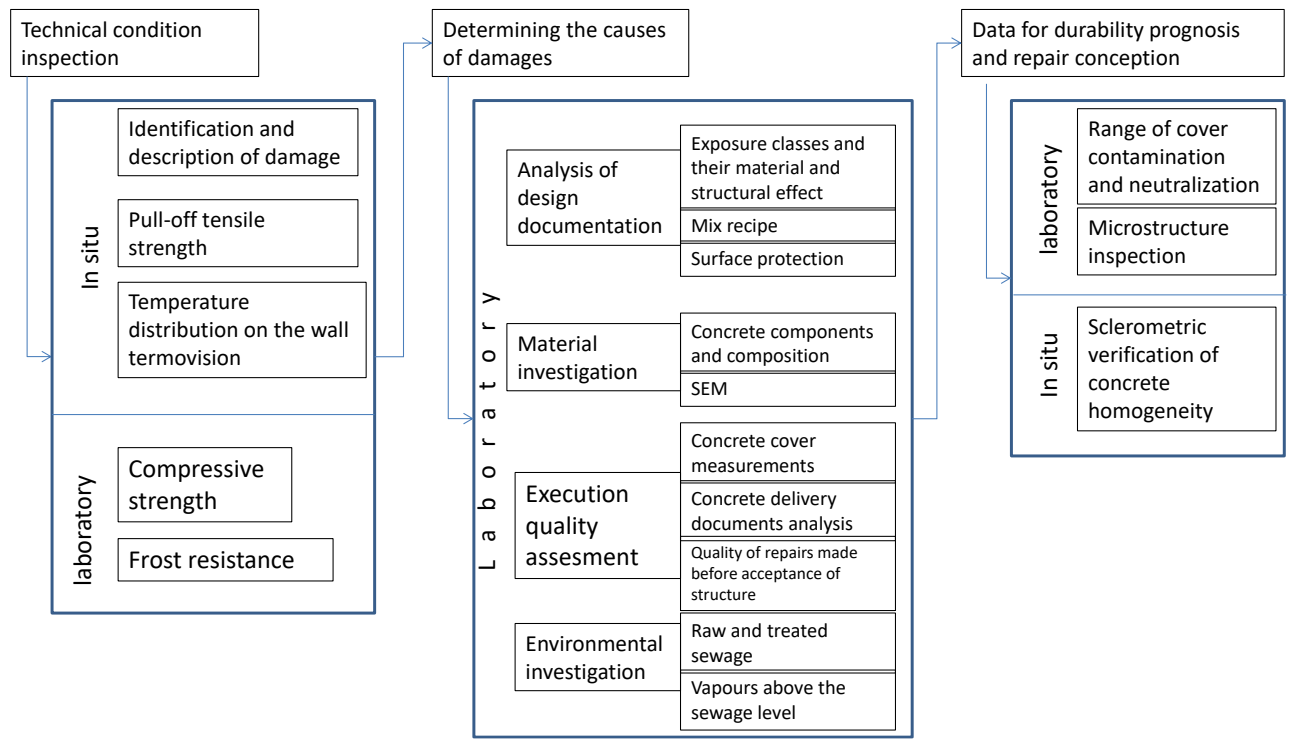

Fig. 3. Diagram of diagnostic procedure.

In the places of detailed inspection of walls, but also in many other areas visible through inspection openings in the roof, signs of advanced surface corrosion of tank walls $01 / 1$ and $02 / 2$ were found. On the other hand, there were no signs of corrosion of the tanks in the building 03 . No corrosion symptoms were found in the lower tank in the building 01 , but it should be noted that the access to this tank was difficult and only fragmentary. The technological scheme of the wastewater treatment indicates that in the above mentioned tanks there are wastewater at various stages of the treatment process, which can cause their different aggressiveness for concrete. 


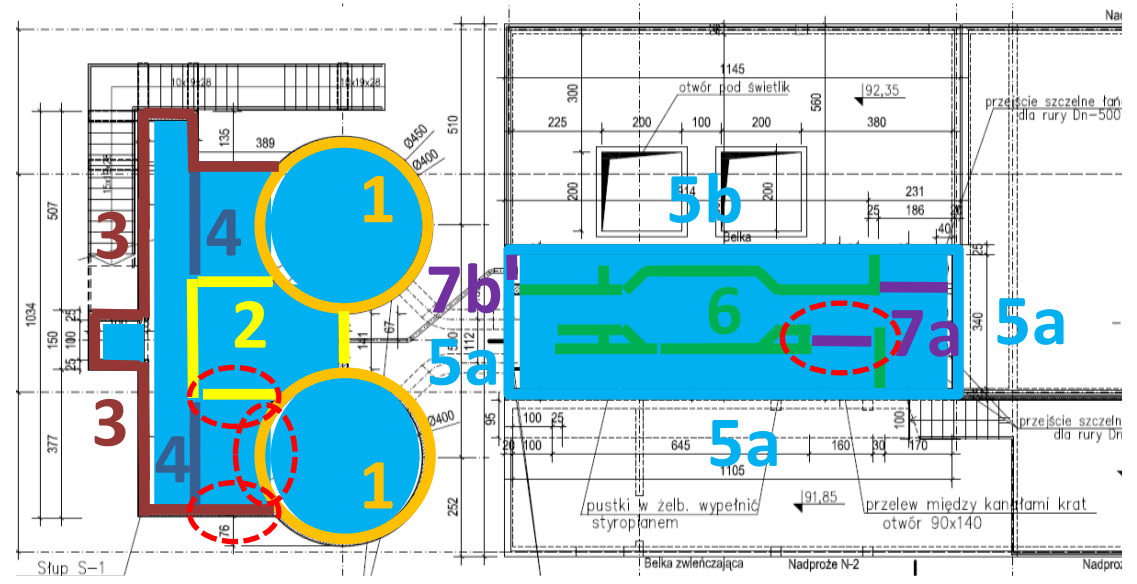

Fig. 4. Different types (different thickness) of walls in the tanks $01 / 1$ and $02 / 2$; elements subject to a detailed inspection and tests - red dotted line.

The tank $01 / 1$ is the closest to the raw sewage inlet. The subject of detailed research in this part was the wall marked as No. 7 (dashed line in the Fig. 4).
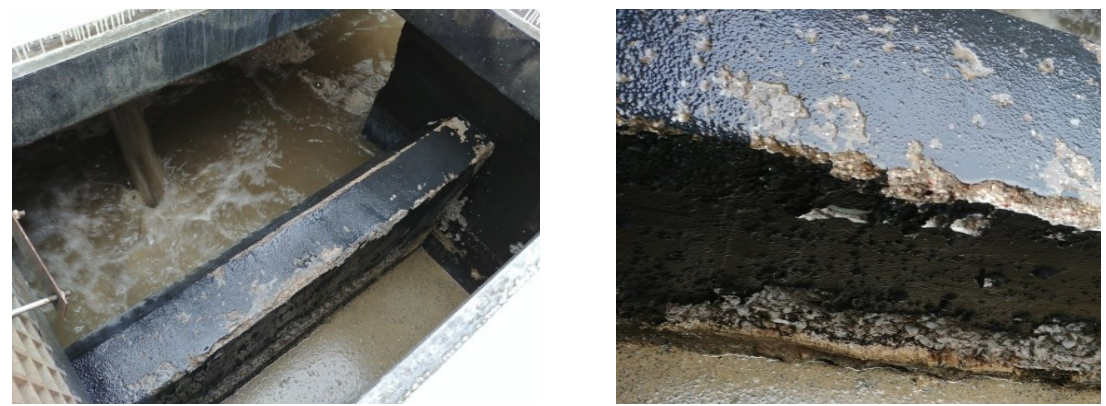

Fig. 5. Damaged surfaces of walls of the tank $01 / 1$.

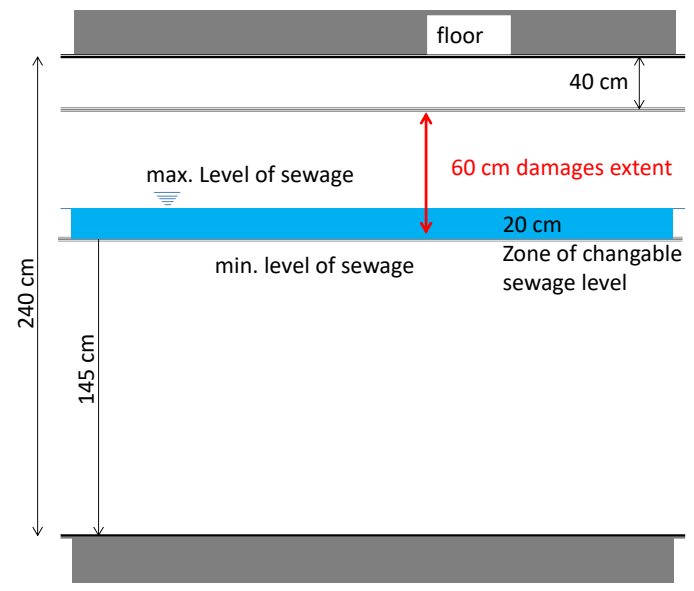

Fig. 6. Estimated extent of damages on the wall height in the tank $01 / 1$.

The walls of the tank $02 / 2$ are in contact with mechanically pre-treated sewage. The subject of detailed research in this part were fragments of the walls marked as No. 1, 2 and 3 (according to the Fig. 4). The internal surfaces of the tank are characterized by numerous 
losses of the bituminous coating and extensive crumbling of the concrete (surface and linear shape) along the edge (Fig. 5 and 7), with an approximate range in the zone above the water level (Fig. 6 and 8). The symptoms found in the tanks $01 / 1$ and $02 / 2$ are similar, although the aggressive environment in both reservoirs could be somewhat different. In both cases the concrete cover damages depth exceeds $2 \mathrm{~cm}$ (Fig. 7).
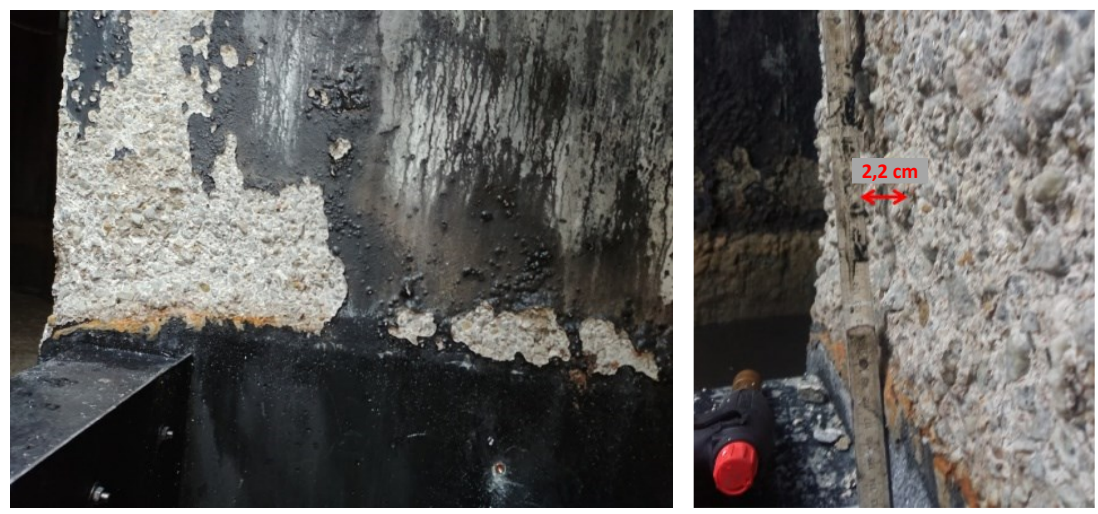

Fig. 7. Damaged surfaces of walls in tank 02/2.

The organoleptic examination proves a significant degree of structural disintegration of concrete - some loosely embedded aggregate grains easily fall out when touched. The vertical range of the above changes includes a zone up to approx. $60 \mathrm{~cm}$ above the wastewater level, i.e. thea zone of fluctuations in the level of wastewater and a spray-gas zone. In the case of the tank $01 / 1$ this means the full usable height of the tank, which may mean in the longer term the propagation of damage to the lower surface of the roof.

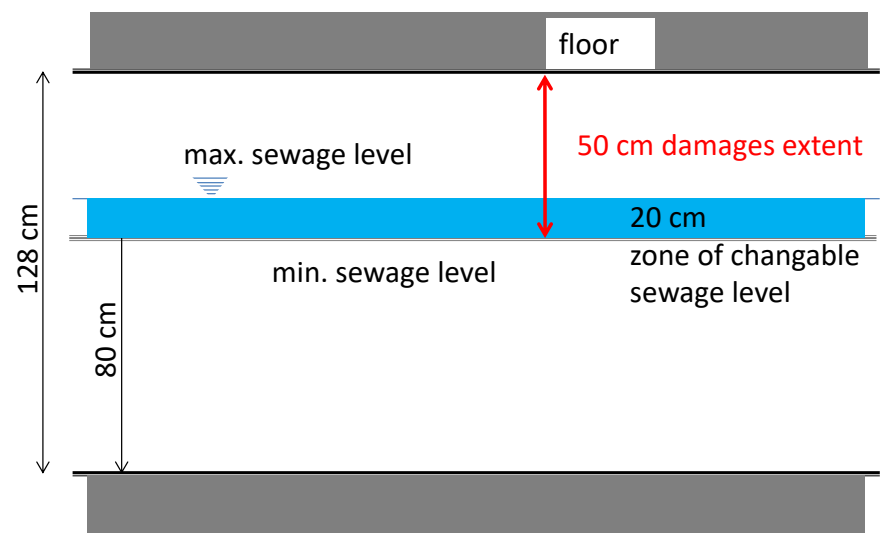

Fig. 8. Estimated extent of damages on the wall height in the tank $02 / 2$.

\section{Investigation of composition and properties of concrete}

The assumptions adopted as the basis for the concrete recipe are generally in line with the requirements specified in the detailed design, with the exception of the exposure class, which should be specified as XA3 according to the design, while the XA2 class (Table 1, col. 2 and 3) is in the recipe. It should be noted, however, that the requirement of strength class $\mathrm{C} 30 / 37$ set in the project does not meet the requirements of the minimum strength class for exposure class XA3 according to PN-EN 206 [3] and PN-B-06265 [4], which is C35/45 (Table 1, Column 3 and 4). The recipe does not contain the results of the control 
tests, but the analysis of the concrete composition allows us to assume that the requirements of the exposure class XA3 could be met.

Table 1. Comparison of requirements for concrete according to specification, recipe and PN-B-06265 standard, (orange color - incompatibility; green - conformity with XA3 class of exposure).

\begin{tabular}{|c|c|c|c|c|}
\hline & \multirow[t]{2}{*}{ Data from recipe } & \multirow[t]{2}{*}{$\begin{array}{l}\text { Requirements from } \\
\text { design specification }\end{array}$} & \multicolumn{2}{|c|}{$\begin{array}{l}\text { Requirements acc. to } \\
\text { PN-B-06265 resulting } \\
\text { from class of exposure }\end{array}$} \\
\hline & & & XA3 & XA2 \\
\hline 1 & 2 & 3 & 4 & 5 \\
\hline Class of exposure & XA2 & XA3 & - & - \\
\hline $\begin{array}{l}\text { Class of compressive } \\
\text { strength }\end{array}$ & $\mathrm{C} 30 / 37$ & C30/37 & C35/45 & $\mathrm{C} 30 / 37$ \\
\hline w/c not higher than & 0.40 & - & 0.45 & 0.50 \\
\hline $\begin{array}{l}\text { Cement content not } \\
\text { lower than }\end{array}$ & 380 & - & 360 & 320 \\
\hline Cement type & $\begin{array}{c}\text { CEM III/A 32,5 N- } \\
\text { NA HSR LH }\end{array}$ & $\begin{array}{c}\text { CEM III/A 32,5 N- } \\
\text { NA HSR LH }\end{array}$ & - & - \\
\hline
\end{tabular}

The results of in-situ tests and laboratory tests of concrete samples (Table 2) lead to the conclusion about the general good quality of concrete in the tank walls. The compressive strength class evaluated on core drillings is significantly higher than assumed by the specification. The concrete surface is characterized by quite high tensile strength (results above $2.5 \mathrm{MPa}$ in the pull-off test), although among 6 results, a value of $0.9 \mathrm{MPa}$ was also obtained, indicating local weakness of the concrete in the tested location. The sclerometer hardness test in different places of the tank wall, near to the places with distinct, deep cavity defects, indicates a high homogeneity of concrete (deviation of the rebound number from 15 measurements is 2.7). High rebound numbers allow to estimate the compressive strength at the level above $50 \mathrm{MPa}$, which was confirmed by the tests of cores. A testing was also carried out to determine the frost resistance of the concrete. Due to the small number of the cores, it was decided to subject a single sample to cycles typical for the study of surface frost resistance in the water saturation conditions. After 56 cycles of such a test, the sample showed no surface flaking. The evaluation of the composition of concrete in the structure showed the use of a granite aggregate with a grain size up to $16 \mathrm{~mm}$, what is in accordance to the recipe. The SEM-EDS tests used for cement type identification showed the presence of slag particles in the concrete, indicating the use of CEM III or CEM II S cement.

Table 2. Results of concrete testing.

\begin{tabular}{|l|l|l|l|}
\hline \multicolumn{2}{|c|}{ Composition } \\
\hline \multirow{2}{*}{ Cement } & type & \multicolumn{1}{c|}{ According to the recipe } & \multicolumn{1}{c|}{ Estimation based on tests } \\
\cline { 2 - 4 } & CEM III/A 32.5 N & $\begin{array}{l}\text { Presence of the slag proven by } \\
\text { SA HSR LH }\end{array}$ & - \\
\cline { 2 - 4 } & content & $380 \mathrm{~kg} / \mathrm{m}^{3}$ & - \\
\hline \multirow{2}{*}{ Aggregate } & fine & Sand $0 / 2 \mathrm{~mm}-650 \mathrm{~kg} / \mathrm{m}^{3}$ & - \\
\cline { 2 - 4 } & coarse & Granite $2 / 8 \mathrm{~mm}-450 \mathrm{~kg} / \mathrm{m}^{3}$ \\
& Granite $8 / 16 \mathrm{~mm}-700 \mathrm{~kg} / \mathrm{m}^{3}$ & $\begin{array}{l}\text { Granite aggregate } \\
\text { Dmax }=16 \mathrm{~mm}\end{array}$ \\
\hline Water & $154 \mathrm{~kg} / \mathrm{m}^{3}$ & - \\
\hline Plasticizer & $1.9 \mathrm{~kg} / \mathrm{m}^{3}$ & - \\
\hline \multicolumn{2}{|l|}{ Superplasticizer } & $1.9 \mathrm{~kg} / \mathrm{m}^{3}$ & - \\
\hline Air-entraining agent & $0.36 \mathrm{~kg} / \mathrm{m}^{3}$ & - \\
\hline
\end{tabular}




\begin{tabular}{|l|l|l|}
\hline \multicolumn{2}{|c|}{ Properties } \\
\hline Consistence & $\mathrm{S} 2 / \mathrm{S} 3 ;$ slump $80-140 \mathrm{~mm}$ & - \\
\hline Air content & $5 \% \pm 1 \%$ & - \\
\hline Compressive strength class & $\mathrm{C} 30 / 37$ & $\mathrm{C} 40 / 50$ \\
\hline Degree of watertightness & $\mathrm{W} 8$ & - \\
\hline $\begin{array}{l}\text { Degree of frost resistance } \\
\text { Surface frost resistance }\end{array}$ & $\mathrm{F} 150$ & - \\
\hline Superficial tensile strength & - & Mass loss, 56 cycles $-0 \%$ \\
\hline Homogeneity & - & $\begin{array}{l}\text { Pull-off } 0.9-4.5 \mathrm{MPa}, \text { destruction } \\
\text { inside concrete }\end{array}$ \\
\hline
\end{tabular}

\section{Investigation and evaluation of environment aggression to reinforced concrete}

\subsection{Sewage samples tests}

The aim of the research was to assess the aggressiveness of sewage into the municipal sewage treatment plant. Two momentary sewage samples were collected: at the input to the treatment plant ("Input"), and after passing through a grid chamber ("Grid") as well as an average daily sample of sewage ("Mixed"). Sampler for daily sample was placed in the input zone of the technological system. The determinations were carried out (Table 3) by the methods recommended in the relevant test standards.

Table 3. Sewage tests results.

\begin{tabular}{|l|l|l|l|l|l|l|l|}
\hline \multirow{2}{*}{ No } & Tested property & \multicolumn{6}{|c|}{ Localisation of sampling } \\
\cline { 3 - 8 } & & Unit & Grid & Input & Grid & Input & Mixed \\
\hline 1 & $\mathrm{pH}$ & & 7.2 & 8 & 7.2 & 7.2 & 7.2 \\
\hline 2 & Conductivity & $\mu \mathrm{S} / \mathrm{cm}$ & 1512 & 1336 & 1369 & 1308 & 1400 \\
\hline 3 & $\mathrm{CO}_{2}$ free & $\mathrm{mg} / 1$ & 39.5 & 15.4 & 26 & 22 & 22 \\
\hline 4 & $\mathrm{CO}_{2}$ aggressive & $\mathrm{mg} / 1$ & 28.6 & 15.4 & 46.2 & 46.2 & 28.6 \\
\hline 5 & General alkalinity & $\mathrm{mmol} / 1$ & 9.2 & 8.5 & 7.9 & 8.4 & 8.1 \\
\hline 6 & Chlorides & $\mathrm{mg} / 1$ & 154 & 110 & 153 & 134 & 142 \\
\hline 7 & Sulphates & $\mathrm{mg} / 1$ & 60 & 90 & 62.5 & 75 & 95 \\
\hline 8 & Calcium & $\mathrm{mg} / 1$ \\
$\mathrm{~mol} / 1$ & $24.9 / 1.04$ & $19.4 / 0.81$ & $20.6 / 1.16$ & $16.8 / 0.7$ & $22.08 / 0.92$ \\
\hline 9 & Magnesium & $\mathrm{mg} / 1$ & $52.8 / 1.32$ & $50.8 / 1.27$ & $54.4 / 1.36$ & $60 / 1.5$ & $56 / 1.4$ \\
\hline 10 & General hardness & $\mathrm{mval} / 1$ & 236 & 208 & 252 & 220 & 232 \\
\hline 11 & $\begin{array}{l}\text { Phosphorus } \\
\text { general }\end{array}$ & $\mathrm{mg} / 1$ & 34 & 22 & 46 & 36 & 40 \\
\hline 12 & Phosphates & $\mathrm{mg} / 1$ & 5.02 & 4.72 & 3.16 & 5.07 & 3.1 \\
\hline 13 & Nitrogen general & $\mathrm{mg} / 1$ & 101.5 & 101.5 & 80 & 84 & 91 \\
\hline 14 & $\begin{array}{l}\text { Nitrate nitrogen } \\
(\mathrm{V})\end{array}$ & $\mathrm{mg} / 1$ & 0.2 & 0 & 0.2 & 0 & 0.2 \\
\hline 15 & $\begin{array}{l}\text { Ammonium } \\
\text { nitrogen }\end{array}$ & $\mathrm{mg} / 1$ & 70 & 80 & 100 & 75 & 95 \\
\hline 16 & Suspension & $\mathrm{mg} / 1$ & 852 & 418 & 426 & 412 & 509 \\
\hline 17 & TOC & $\mathrm{mg} / 1$ & 214 & 259 & 67.31 & 68.47 & 67.21 \\
\hline 18 & COD & $\mathrm{mg} / 1$ & 720 & 440 & 395 & 434 & 474 \\
\hline 19 & BOD 5 & $\mathrm{mg} \mathrm{O} / 1$ & 245 & 185 & 136.6 & 151.6 & 131.4 \\
\hline
\end{tabular}




\subsection{Air samples tests}

Air samples were collected directly above the surface of the sewage at five locations in the area of tanks $01 / 1$ and $02 / 2$. The concentration of hydrogen sulphide, ammonia and carbon dioxide in the area above the surface of the sewage level was determined (Table 4).

Table 4. Results of air testing.

\begin{tabular}{|c|c|c|c|c|c|}
\hline \multirow{2}{*}{ Substance } & \multicolumn{5}{|c|}{ Measuring place } \\
\cline { 2 - 6 } & 1 & 2 & 3 & 4 & 5 \\
\hline $\mathrm{H}_{2} \mathrm{~S}\left[\mathrm{mg} / \mathrm{m}^{3}\right]$ & 14.99 & 16.23 & 24.97 & 33.0 & 29.97 \\
\hline $\mathrm{NH}_{3}\left[\mu \mathrm{g} / \mathrm{m}^{3}\right]$ & 79.9 & 159.8 & 159.8 & 159.8 & 320 \\
\hline $\mathrm{CO}_{2}\left[\mathrm{mg} / \mathrm{m}^{3}\right]$ & 978.7 & 730.2 & 1071.5 & 1139.0 & 1341.5 \\
\hline
\end{tabular}

\subsection{Temperature distribution on the walls of reinforced concrete tanks}

Infrared photos of the interior of the tanks (Figure 9) were used to estimate the temperature distribution on the walls in the zone above the sewage level. During measurements, the temperature of the atmospheric air was $-2{ }^{\circ} \mathrm{C}$ to $-3^{\circ} \mathrm{C}$. It was found that the surface temperature of the concrete wall of the tank 02/2 at the level of the sewage level (about $1 \mathrm{~m}$ below the top of the tank) under these conditions was approx. $12^{\circ} \mathrm{C}$ and decreased towards the top of the tank by approx. $5^{\circ} \mathrm{C} / \mathrm{m}$. This means that - assuming a constant temperature of sewage - already at a drop in air temperature to the level of $-9^{\circ} \mathrm{C}$, the temperature of the wall surface can be expected to fall below zero, even in a deeper water tank $02 / 2$, in the zone of observed concrete damage.
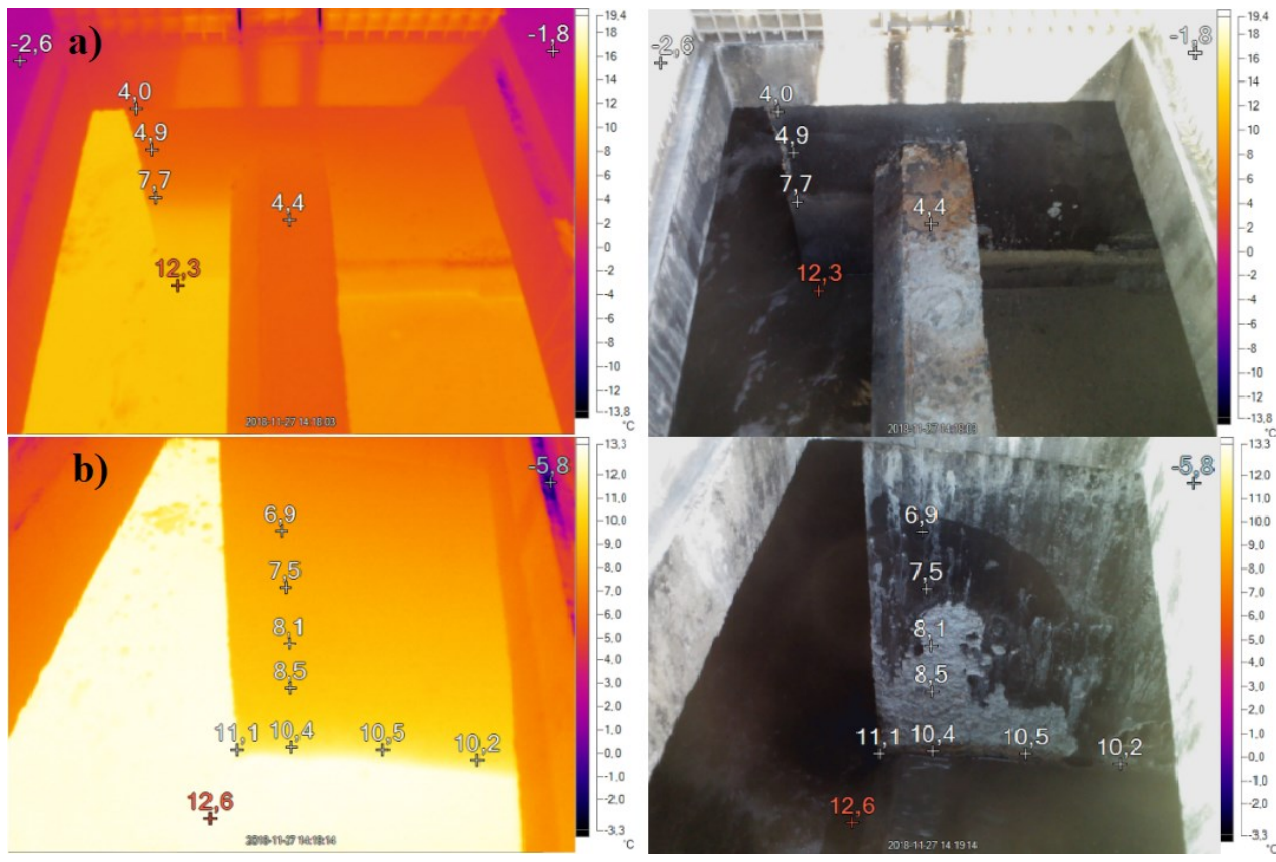

Fig. 9. Infrared photos: a) tank $01 / 1$; b) tank $02 / 2$ 


\subsection{Assessment of the potential aggressiveness of the environment for reinforced concrete}

\subsubsection{Agressiveness of factors detected in sewage}

The risk of chemical aggression for concrete in sewage treatment plant objects results from the composition of the liquid acting on concrete elements and gases located in the space above the surface of the liquid [1].

Among substances whose content has been determined in sewage, direct corrosive action against concrete can show (according to European Standard PN-EN 206 "Concrete" [3]):

- sulphates $\left(\mathrm{SO}_{4}{ }^{2-}\right.$ ions $)$ - destruction is observed as an effect of formation of ettringite $\left(6 \mathrm{CaO} \cdot \mathrm{Al}_{2} \mathrm{O}_{3} \cdot 3 \mathrm{SO}_{3} \cdot 32 \mathrm{H}_{2} \mathrm{O}\right)$, which crystallize with increasing of the volume,

- acids $\left(\mathrm{H}^{+}\right.$ions $)$- destruction is observed as an effect of formation of easily soluble salts, which could leach from concrete [5],

- $\quad$ aggressive carbon dioxide $\left(\mathrm{CO}_{2}\right.$ aggr $)$ - product leaching from concrete is calcium hydrogen carbonate $\mathrm{CaHCO}_{3}$,

- ammonium ions $\left(\mathrm{NH}_{4}^{+}\right)$- destruction is observed as an effect of calcium substitution by ammonium ions - this leads to ammonium hydroxide formation and its transformation into ammonia gas $\mathrm{NH}_{3}$, which evaporates from concrete and in consequence increases concrete porosity,

- magnesium ions $\left(\mathrm{Mg}^{2+}\right)$ - destruction is observed as an effect of calcium substitution by magnesium ions - this leads to formation of magnesium hydroxide, which has no binding properties.

As a part of this work, the determinations of concentrations of substances found in sewage was done (Table 3). Based on the results of these determinations it can be concluded that among the potentially hazardous factors, aggressive carbon dioxide and ammonium ions are present in the quantities that can be a real threat to the reinforced concrete (Table 5). The lack of acid aggressiveness is additionally confirmed by high general alkalinity $\left(Z_{\mathrm{og}}\right)$, not less than $7.9 \mathrm{mmol} / \mathrm{l}$, ie. $86.9 \mathrm{mg}$ of $\mathrm{CO}_{2}$. This means that equilibrium $\mathrm{pH}\left(\mathrm{pH}_{\mathrm{n}}\right)$, estimated with formula $\mathrm{pH}_{\mathrm{n}}=11,39-2 \log \mathrm{Z}_{\mathrm{og}}$, is ca. 3.9. Langelier`s index $\mathrm{IL}=\mathrm{pH}-\mathrm{pH}_{\mathrm{n}}=3.3$, which means that there is no acidic aggression [6,7].

Table 5. Assessment of chemical aggression for concrete with substances present in sewage.

\begin{tabular}{|c|c|c|}
\hline Aggressive factor & Content in sewage & Evaluation of aggressiveness \\
\hline Sulphates & $60 \div 95 \mathrm{mg} / \mathrm{l}$ & $\begin{array}{l}\text { No risk of corrosion acc. to PN-EN } 206 \\
\text { (risk at the content }>200 \mathrm{mg} / \mathrm{l} \text { ) }\end{array}$ \\
\hline $\mathrm{pH}$ & $7.2 \div 8$ & $\begin{array}{l}\text { No risk of corrosion acc. to PN-EN } 206 \\
\text { (risk at the value of } \mathrm{pH}<6.5 \text { ) }\end{array}$ \\
\hline $\mathrm{CO}_{2}$ aggressive & $15.4 \div 46.2 \mathrm{mg} / 1$ & $\begin{array}{l}\text { Threat }- \text { exposure class XA1 (at the content } 15 \\
\div 40 \mathrm{mg} / \mathrm{l} \text { ) or XA2 (at the cntent } 40 \div 100 \mathrm{mg} / \mathrm{l} \text { ) } \\
\text { acc. to PN-EN } 206\end{array}$ \\
\hline $\mathrm{NH}_{4}^{+}$ & $\begin{array}{l}\text { Ammonium nitrogen: } 70 \\
\div 100 \mathrm{mg} / \mathrm{l} \text {, which means: } \\
\quad 90 \div 130 \mathrm{mg} / \mathrm{l} \mathrm{NH} 4^{+}\end{array}$ & $\begin{array}{l}\text { Big threat }- \text { exposure class XA3 (at the content } \\
60 \div 100 \mathrm{mg} / \mathrm{l}) \text { and above the scale }(>100 \mathrm{mg} / \mathrm{l}) \\
\text { acc. to PN-EN } 206\end{array}$ \\
\hline $\mathrm{Mg}^{2+}$ & $50 \div 60 \mathrm{mg} / \mathrm{l}$ & $\begin{array}{l}\text { No risk of corrosion acc. to PN-EN } 206 \\
\text { (risk at the content }>300 \mathrm{mg} / \mathrm{l} \text { ) }\end{array}$ \\
\hline
\end{tabular}


The other substances marked in the sewage do not constitute a chemical hazard for the concrete. The $\mathrm{BOD}_{5}$ and $\mathrm{COD}$ values are at the level typical for municipal sewage and do not indicate a significant risk of generating of additional aggressive factors $\left(\mathrm{H}_{2} \mathrm{~S}\right.$ and $\left.\mathrm{CO}_{2}\right)$ in the process of decay (uncontrolled fermentation of organic components under anaerobic conditions).

\subsubsection{Aggressiveness of gaseous substances}

The aggressive factor for concrete is primarily the hydrogen sulfide present in the space above the sewage [8]. Carbon dioxide may also be dangerous for reinforced concrete [9].

Under anaerobic conditions, sulfur-reducing bacteria produce hydrogen sulphide $\left(\mathrm{H}_{2} \mathrm{~S}\right)$ from sulfur compounds present in wastewater. After $\mathrm{H}_{2} \mathrm{~S}$ has been emitted into the airspace of channels, it is re-oxidized to elemental sulfur and then, by sulfur oxidizing bacteria, to biogenic sulfuric acid(VI). In this way, the concrete in the space above the liquid level is particularly exposed to the acid and sulphate corrosion [8].

As a part of this work, the determinations of concentrations of gaseous substances in the space above the sewage were done (Table 7). In the table 9 an assessment of corrosion risk for concrete and reinforced concrete is evaluated. Since the European Standard PN-EN 206 [2] does not refer to the aggressiveness of gas environments, the assessment was based on the (outdated) Polish Standard PN-B-01800:1980 "Anticorrosive protection in construction - Concrete and reinforced concrete structures - Classification and determination of environments" [10].

On the basis of the results it can be concluded that among the potentially dangerous factors, carbon dioxide and above all hydrogen sulphide are present in amounts that could be dangerous for the reinforced concrete. The gaseous carbon dioxide may lead to a decrease of alkalinity of the concrete cover and, as a consequence, to the corrosion of the steel reinforcement; however, the concentration of $\mathrm{CO}_{2}$ is not very high (the corrosion risk of the reinforced concrete occurs, but is low). The presence of hydrogen sulphide in the determined concentration can, however, result in the initiation of corrosive processes (acid and sulphate corrosion) [11].

Table 6. Assessment of chemical aggression for concrete with substances present in the air above the sewage level.

\begin{tabular}{|l|c|l|}
\hline \multicolumn{1}{|c|}{ Aggressive factor } & Content in sewage & \multicolumn{1}{c|}{ Aggressiveness evaluation } \\
\hline $\begin{array}{l}\text { Hydrogen sulphide } \\
\mathrm{H}_{2} \mathrm{~S}\end{array}$ & $14 \div 33 \mathrm{mg} / \mathrm{m}^{3}$ & $\begin{array}{l}\text { Medium risk of corrosion (ma) of concrete, high } \\
\text { risk of corrosion }\left(\mathrm{h}_{\mathrm{a}}\right) \text { of reinforced concrete }\end{array}$ \\
\hline Amonia $\mathrm{NH}_{3}$ & $80 \div 320 \mu \mathrm{g} / \mathrm{m}^{3}$ & No risk of corrosion \\
\hline $\begin{array}{l}\text { Carbon dioxide } \\
\mathrm{CO}_{2}\end{array}$ & $730 \div 1342 \mathrm{mg} / \mathrm{m}^{3}$ & $\begin{array}{l}\text { No risk of corrosion of concrete, low risk of } \\
\text { corrosion }\left(\mathrm{l}_{\mathrm{a}}\right) \text { of reinforced concrete }\end{array}$ \\
\hline
\end{tabular}

\subsubsection{Thermal treat}

The analysis of thermovision measurements of the internal surfaces of tanks allows to assess that there is a real threat of negative temperature impact in the tank's splash-gas zone. It is estimated that in the case of lowering the outside temperature down to $-9^{\circ} \mathrm{C}$, there is possibility of freezing the surface of the tank $02 / 2$ slightly above the wastewater level. The cyclical occurrence of this phenomenon together with high humidity of concrete leads to the classification of the environment aggressiveness as XF3 exposure class. In the case of tank $01 / 1$, in which the distance from the bottom of the tank to the sewage level is smaller, the risk of freezing occurs at a relatively higher temperature. 


\section{Conclusions}

The conducted diagnostic tests and the analysis of available documentation indicate that in the case of the analyzed tanks no obvious errors related to concrete technology were made. The composition and components of the concrete are generally consistent with the conditions of exposure adopted in the project, and the quality of concrete indicates that the suitable technological regime was kept. However, the structural and surface protection proved to be insufficient, as evidenced by the very rapid progress of destruction of concrete on the surfaces most exposed to the aggressive factors. The analysis of aggressive factors acting in the facility indicates that, especially in the area of variable level of the wastewater, the aggressiveness of the environment for concrete was underestimated at the designing stage. Not only the high concentration of some chemically aggressive media (ammonia and carbon dioxide in wastewater, hydrogen sulphide in vapours above sewage level) is important, but also their synergic effect on the concrete. In addition, this phenomenon is intensified by alternating cycles of moistening and drying of concrete, as well as its freezing and thawing. In such complex and aggressive conditions of exposure it is particularly important to comply with the highest standards in both material and structural protection as well as surface protection of concrete.

\section{References}

1. P. Woyciechowski, J.J. Sokołowska, B Jaworska, Ochrona przed Korozją, 1 (2016)

2. F.R. Spellman, Handbook of Water and Wastewater Treatment Plant Operations (CRC Press Taylor\& Francis Group, 2013)

3. PN-EN 206:2014: Concrete - Specification, performance, production and conformity

4. PN-B-06265:2018: Beton -- Wymagania, właściwości, produkcja i zgodność - Krajowe uzupełnienie PN-EN 206+A1:2016-12 [in Polish]

5. P. Woyciechowski, J. Sokołowska, G. Adamczewski, Adv. Mat. Res. 687, pp. 144-149 (2013)

6. Evaluation of the aggressiveness and corrosive properties of water (University of Gdansk, Department of Environment Analysis, Gdansk 2014) [in Polish]

7. W. Hermanowicz, J. Dojlido, W. Dożańska, B. Koziorowski, J. Zerbe, Physical and chemical testing of water and wastewater (Arkady, Warszawa, 1999) [in Polish]

8. J.J. Sokołowska, P. Woyciechowski, Int. Conf. On Sust. Mat. Tech., Kioto (2013)

9. P. Woyciechowski, BMC 10, (2013)

10. PN-B-01800:1980: Antykorozyjne zabezpieczenia w budownictwie -- Konstrukcje betonowe i żelbetowe -- Klasyfikacja i określenie środowisk [in Polish]

11. M. Alexander, A. Bentur, S. Mindess, Durability of concrete. Design and construction (CRC Press Taylor\& Francis Group, 2017) 